ignored Ukrainian claims although they readily ate Ukrainian bread. Elwood neglects such ethnically Ukrainian Marxists as Volodymyr Zatons'kii and Mykola Skrypnyk. He does not utilize Lev Iurkevych's (Rybalka's) work, The Russian Social Democrats and the Nationality Question, published in Geneva in 1917, although he does allude to the disagreement between Iurkevych and Lenin, and Lenin's mendacious efforts to discredit Iurkevych. Elwood concludes that "Lenin's attitude toward Ukrainians probably should be suspect" (p. 263).

The author recognizes that the Ukrainian Nationalists outnumbered the Russian Social Democrats who were incapable of thinking "in Ukrainian terms" and had nothing to offer the Ukrainian nation or its peasantry. They published nothing in the Ukrainian language and lived in their own urban world. The fact that RSDRP membership in the Ukraine declined to three hundred in 1909 indicates the basic weakness of its position, although it was able to make slight gains after 1911 by shifting to "legal" activities and the use of front organizations. Elwood's book provides a valuable supplement to Arthur Adams's Bolsheviks in the Ukraine in explaining the circumstances and attitudes that led to the failure of Lenin's policies in 1917-20. The author also demolishes certain myths that have been assiduously cultivated and propagated in Soviet party historiography.

John S. Reshetar, JR. University of Washington

\title{
SOTSIAL'NO-POLITICHESKOE RAZVITIE GORODOV BELORUSSII V XVI-PERVOI POLOVINE XVII V. By Z. Iu. Kopysskii. Minsk: Izdatel'stvo "Nauka i tekhnika," 1975. 189 pp. 95 kopecks.
}

This work complements the author's earlier economic analysis of Belorussian towns and urban institutions. The prime focus is on urban self-government, which Kopysskii postulates as the most important feature of urban development, especially with the development of Magdeburg Law. This emphasis puts him squarely in the tradition of European urban scholarship-with Pirenne, Rörig, and Weber-and defines the character of his study.

According to Kopysskii, Magdeburg Law was grafted onto extant urban institutions during a period of intense crisis and change, but without essentially altering urban residents' participation in local affairs. They continued to take an active role in urban elections and displayed a political initiative not provided for in the code. Rather than establishing the concept of self-government per se, this form of urban government replaced prior institutions common to Belorussian towns. The author also carefully notes the importance of urban oligarchies in the administration and official life of the towns, arguing cogently that Magdeburg Law and self-government were not necessarily democratic and representative phenomena.

His concentration on self-government, with occasional enlightening references to West European towns, creates a constricting framework already familiar from other studies in urban history. It is apparently uncomfortable for Kopysskii as well. Although his analysis leads him to the conclusion that towns did not influence internal or external change, he asserts early in the book that the evolution of towns shaped the policies of higher powers, not vice versa. Unfortunately, he does not pursue this potentially more original line of argument.

His analysis provides valuable information for a comparative study of Russian and European towns, along with an important discussion of Magdeburg Law. It deserves a wider audience among European historians than it will probably receive.

David H. Miller

Rutgers University 